\title{
ATIKAN UNPAD: UPAYA PENINGKATAN PARTISIPASI DAN PENYELESAIAN SEKOLAH TINGKAT DASAR DAN MENENGAH DI PEDESAAN JAWA BARAT
}

\author{
D. Chaerani., Kurnia, D., Darmayanti, N., Dewanto, S.P., \\ Safriani, L., Irawan, B., Firdaniza, Kusuma, D.A. danSantoso, M.B. \\ ${ }^{1}$ Program Studi S1 Matematika, Fakultas MIPA, Universitas Padjadjaran \\ ${ }^{2}$ Program Studi S1 Kimia Fakultas MIPA Universitas Padjadjaran \\ ${ }^{3}$ Program Studi Bahasa Indonesia Fakultas Ilmu Budaya Universitas Padjadjaran \\ ${ }^{4}$ Program Studi S1 Fisika Fakultas MIPA Universitas Padjadjaran \\ ${ }^{5}$ Program Studi S1 Biologi Fakultas MIPA Universitas Padjadjaran \\ ${ }^{6}$ Program Studi S1 Kesejahteraan Sosial FISIP Universitas Padjadjaran \\ Email: d.chaerani@unpad.ac.id
}

\begin{abstract}
ABSTRAK
Dalam pelaksanaan Program Pengadian Pada Masyarakat (PPM) Prioritas Universitas Padjadjaran 2014 ini, berbagai kegiatan telah dilakukan dalam rangka mewujudkan capaian kegiatan dalam hal upaya peningkatan partisipasi dan penyelesaian sekolah tingkat dasar dan tingkat menengah di pedesaan Jawa Barat. Dalam hal ini yang menjadi perhatian kami adalah apa yang dapat dilakukan tim PPM Prioritas Atikan Unpad untuk membantu Unit Pelaksanaan Teknis Daerah untuk TK/SD dan Pendidikan Non Formal dalam hal menangani masyarakat putus sekolah dan anak-anak usia pra sekolah dasar di pedesaan Jawa Barat. Target masyarakat yang menjadi sasaran kegiatan kami adalah Pusat Kegiatan Belajar Masyarakat (PKBM), Kelompok Belajar, Pendidikan Usia Dini dan Taman Kanak-kanak/ Raudhatul Athfal. Lokasi PPM yang kami pilih adalah Desa Jatimukti Kecamatan Jatinangor Kabupaten Sumedang. Pelatihan Learning Skills diberikan untuk meningkatkan kemampuan para tutor dan guru dalam mengelola diri serta warga belajar didikannya. Secara umum, hasil dari kegiatan ini menunjukkan peningkatan antusiasme belajar dari warga belajar, tutor, pengelola PKBM serta para guru TK/PAUD. Diharapkan kegiatan ini dapat meningkatkan angka partisipasi dan penyelesaian sekolah tingkat dasar dan menengah.
\end{abstract}

Kata Kunci: atikan unpad, angka partisipasi kasar, putus sekolah, kejar paket, PKBM,

\section{ABSTRACT}

In the implementation of the Pengadian Pada Masyarakat Program (PPM) Priority Padjadjaran University in 2014, various activities have been carried out in order to realize the achievements of activities in terms of efforts to increase school participation and completion of primary and secondary levelin rural West Java. In this case that concerns us is what canbe done to assist the Regional chnical Implementation Unit for Kindergarten/Primary and NonFormal Educationin terms of dealing with the drop out and preschool children in a rural primary schoolin West Java. Target people who become targets of our activitiesis the Community Learning Center(CLC), GroupLearning, Early Childhood Education and Preschool/Raudhatul RA. The location PPM that we choose is the Village Jatimukti Jatinangor District of Sumedang District. Learning Skills Training is given to improve the skills of tutors and teachers in managing the mselves and their students. In general, the results of this work showan in creasel earning enthusiasm of the learners, tutors, managers and teachers CLC kindergarten/early childhood. This activity can be expected to in creaseen roll ment and completion of primary and secondary schools.

Key words: Atikan Unpad, Angka Partisipasi Kasar, Drop-out, Kejar Paket C, CLC

\section{PENDAHULUAN}

\section{Analisis Situasi}

Dalam pelaksanaan Program Pengadian Pada Masyarakat (PPM) Prioritas Universitas Padjadjaran 2014 ini, berbagai kegiatan telah dilakukan dalam rangka mewujudkan capaian kegiatan dalam hal upaya peningkatan partisipasi dan penyelesaian sekolah tingkat dasar dan tingkat menengah di pedesaan Jawa Barat. Dalam hal ini yang menjadi perhatian kami adalah apa yang dapat dilakukan tim PPM Prioritas Atikan Unpad untuk membantu Unit Pelaksanaan Teknis Daerah untuk TK/SD dan Pendidikan Non Formal dalam hal menangani masyarakat putus sekolah dan anak-anak usia pra sekolah dasar di pedesaan Jawa Barat. Target masyarakat yang menjadi sasaran kegiatan kami adalah Pusat Kegiatan Belajar Masyarakat (PKBM), Kelompok Belajar, Pendidikan Usia Dini dan Taman Kanak-kanak/Raudhatul Athfal. Lokasi PPM yang kami pilih adalah Desa Jatimukti Kecamatan Jatinangor Kabupaten Sumedang, Desa Cibeusi Kecamatan Jatinangor Kabupaten Sumedang, dan Desa Mekarjaya Kecamatan Bayongbong Kabupaten Garut.

Berdasarkan hasil analisis situasi pada lokasi PPM Prioritas yang telah kami pilih, maka bentuk kegiatan yang kami laksanakan adalah pendampingan dan pemberian suplemen pengajaran bagi warga belajar pada Program Kejar Paket C di adalah Desa Jatimukti Kecamatan Jatinangor Kabupaten Sumedang; pendampingan dan pengembangan PKBM Linuhung Desa Cibeusi Kecamatan Jatinangor Kabupaten Sumedang; memperkenalkan pentingnya pembentukan PKBM dan Taman Bacaan Masyarakat di Desa Mekarjaya Kecamatan Bayongbong Kabupaten Garut; Pelatihan Learning Skills bagi seluruh mitra PPM yang terlibat dalam hal ini adalah para tutor dan warga belajar kejar paket C Desa Jatimukti, pengurus PKBM Linuhung serta guru TK/ PAUD dari PKBM Linuhung dan Desa Mekarjaya.

Dalam hal kegiatan pendampingan Program Kejar Paket C di Desa Jatimukti, faktor penghambat yang dapat disebutkan bahwa aspek kognitif, 
psikomotorik dan afektif warga belajar dalam hal penguasaan materi ujian nasional kesetaraan dapat dinilai rendah. Sementara itu dalam kurun waktu kurang dari 6 bulan, peserta program kejar paket $\mathrm{C}$ ini akan mengikuti ujian nasional kesetaraan. Hal ini terlihat dari hasil pre-test dan post-test yang dilakukan pada dosen pelaksana kegiatan. Selain itu, minimnya sarana prasarana pengajaran merupakan salah satu factor penghambat yang patut untuk disebutkan. Hal lain yang perlu disebutkan adalah rendahnya tingkat konsistensi warga belajar dalam mengikuti Program Kejar Paket C. Hal ini terlihat dari kehadiran warga belajar yang kurang dari 50\% pada setiap sesi yang diselenggarakan. Selain itu, Pengamatan tim PPM Prioritas Atikan Unpad, para tutor Program Kejar Paket $\mathrm{C}$ untuk setiap mata pelajaran terkait terlihat tidak turut hadir dalam masa pendampingan. Hal ini mengakibatkan terdapat hambatan bagi tim PPM untuk dapat melihat kedalaman materi yang diajarkan oleh para tutor kepada warga belajar.

Namun demikian, faktor pendorong dalam kegiatan ini adalah dukungan serta sikap yang sangat kooperatif dari para pejabat setempat dalam hal pelaksanaan kegiatan ini patut disebutkan. Yayasan Linuhung selaku pengelola PKBM Linuhung di Desa Cibeusi kami jadikan PKBM percontohan bagi Desa Jatimukti dan Desa Mekarjaya. Dalam hal ini Desa Jatimukti dan Desa Mekarjaya dipilih sebagai lokasi PPM yang belum memiliki PKBM. Sehingga diharapkan pendampingan bagi Desa Jatimukti dan Mekarjaya dapat berlanjut di masa yang akan datang, dalam hal pendampingan pembentukan PKBM dengan menambahkan beberapa kegiatan masyarakat dalam hal ini termasuk memberikan bantuan pada RA Al Maasy dan Kelompok Bermain Insan Rabbani, serta diharapkan dapat terbentuk taman bacaan masyarakat, kelompok belajar kejar paket $\mathrm{C}$, serta kelompok usaha serta pelatihan/kursus. Pelatihan Learning Skills diberikan untuk meningkatkan kemampuan para tutor dan guru dalam mengelola diri serta warga belajar didikannya.

Secara umum, hasil dari kegiatan ini menunjukkan peningkatan antusiasme belajar dari warga belajar, tutor, pengelola PKBM serta para guru TK/PAUD. Diharapkan kegiatan ini dapat meningkatkan angka partisipasi dan penyelesaian sekolah tingkat dasar dan menengah.

\section{SUMBER INSPIRASI}

\section{Tujuan Pembangunan Milenium Indonesia}

Sebagaimana disebutkan dalam Laporan Perkembangan Pencapaian Tujuan Pembangunan Milenium Indonesia (BAPPENAS, 2012).Terdapat 8 (delapan) tujuan Millinium Development Goals (MDGs) yang telah ditentukan dalam pembangunan Indonesia. Hingga tahun 2012, tujuan MDGs yang telah tercapai adalah:

1. MDG 1, yaitu proporsi penduduk dengan pendapatan kurang dari USD 1,00 (PPP) per kapita per hari.

2. MDG 3, yaitu rasio APM perempuan terhadap laki-laki SMA/MA/Paket $\mathrm{C}$ dan rasio angka melek huruf perempuan terhadap laki-laki umur 15-24 tahun.
3. MDG 6, yaitu pengendalian penyebaran dan penurunan jumlah kasus baru tuberkulosis (TB). Pencapaian ini diindikasikan oleh angka kejadian dan tingkat kematian, serta proporsi tuberkulosis yang ditemukan, diobati dan disembuhkan dalam program DOTS.

Sementara itu, seperti juga disebutkan dalam Laporan yang sama, tujuan MDGs yang telah menunjukkan kemajuan signifikan dan diharapkan dapat tercapai pada tahun 2015 (on-track) adalah:

1. MDG 1, yaitu terdapat kemajuan yang sangat besar dari indeks kedalaman kemiskinan, proporsi tenaga kerja yang berusaha sendiri dan pekerja bebas keluarga terhadap total kesempatan kerja, dan prevalensi balita dengan berat badan rendah/ kekurangan gizi.

2. MDG 4, yaitu penurunan yang sudah mendekati dua pertiga angka kematian neonatal, bayi, dan balita serta proporsi anak usia 1 tahun yang mendapat imunisasi campak yang meningkat pesat.

3. MDG 5, yaitu berupa peningkatan angka pemakaian kontrasepsi bagi perempuan menikah dengan menggunakan cara modern, penurunan angka kelahiran remaja perempuan umur 15-19 tahun, peningkatan cakupan pelayanan antenatal baik 1 maupun 4 kali kunjungan, dan penurunan kebutuhan KB yang tidak terpenuhi (unmet need).

4. MDG 6, yaitu mengendalikan penyebaran dan penurunan jumlah kasus baru HIV dan AIDS berupa peningkatan proporsi penduduk terinfeksi HIV lanjut yang memiliki akses pada obat-obatan Antiretroviral (ARV). MDG 7, yaitu berupa penurunan konsumsi bahan perusak ozon, proporsi tangkapan ikan yang tidak melebihi batas biologis yang aman, serta rasio luas kawasan lindung untuk menjaga kelestarian keanekaragaman hayati terhadap total luas kawasan hutan dan rasio rasio kawasan lindung perairan terhadap total luas perairan teritorial yang keduanya meningkat.

5. MDG 8, yaitu berupa keberhasilan pengembangan sistem keuangan dan perdagangan yang terbuka, berbasis peraturan, dapat diprediksi dan tidak diskriminatif yang diindikasikan oleh rasio ekspor dan impor terhadap PDB, rasio pinjaman terhadap simpanan di bank umum, dan rasio pinjaman terhadap simpanan di BPR yang semuanya meningkat pesat. Selain itu juga keberhasilan dalam menangani utang untuk dapat mengelola utang dalam jangka panjang yang diindikasikan oleh rasio pinjaman luar negeri terhadap PDB dan rasio pembayaran pokok utang dan bunga utang luar negeri terhadap penerimaan hasil ekspor yang menurun tajam. Keberhasilan selanjutnya adalah dalam hal pemanfaatan teknologi informasi dan komunikasi, yang diindikasikan oleh peningkatan proporsi penduduk yang memiliki jaringan telepon tetap dan telepon seluler.

\section{Angka Partisipasi Kasar Jawa Barat}

Dalam kegiatan PPM Prioritas ini, diusulkan untuk melakukan suatu upaya dalam hal Peningkatan Partisipasi dan Penyelesaian Pendidikan Sekolah 
Dasar dan Menengah di Pedesaan Jawa Barat untuk mendukung pencapaian MDGs 2 dan MDGs 3. Untuk mewujudkan MDGs 2 dan 3, salah satu parameter ukuran yang dapat digunakan adalah Angka Partisipasi Kasar (APK) Pendidikan.

Dalam laporan (Ridwan, 2014) pada website Lensa Indonesia disebutkan bawah Direktur Jenderal Pendidikan Menengah Kementerian Pendidikan dan Kebudayaan (Dirjen Dikmen Kemdikbud) Prof Achmad Jazidie menegaskan Angka Partiisipasi Kasar (APK) di Jawa Barat jauh di bawah standart nasional. Padahal, setiap tahun APK di daerah lain terus mengalami peningkatan.

Angka Partisipasi Kasar (APK), menunjukkkan partisipasi penduduk yang sedang mengenyam pendidikan sesuai dengan jenjang pendidikannya. Angka Partisipasi Kasar (APK) merupakan persentase jumlah penduduk yang sedang bersekolah pada suatu jenjang pendidikan (berapapun usianya) terhadap jumlah penduduk usia sekolah yang sesuai dengan jenjang pendidikan tersebut.

APK digunakan untuk mengukur keberhasilan program pembangunan pendidikan yang diselenggarakan dalam rangka memperluas kesempatan bagi penduduk untuk mengenyam pendidikan. APK merupakan indikator yang paling sederhana untuk mengukur daya serap penduduk usia sekolah di masing-masing jenjang pendidikan.

Dari data yang ada di Dikmen Kemdikbud, tahun 2012 secara Nasional sudah mencapai angka 76,44 persen, APK tertinggi adalah Provinsi Bali yaitu 105,94 persen. Sedangkan Provinsi Jabar baru mencapai 67,77 persen atau berada diurutan ke 28. Kendati mayoritas APK daerah di Indonesia mengalami peningkatan yang cukup cepat namun ada juga yang stagnan, seperti di Jabar ini.

Dikatakan, adanya kesenjangan APK antar provinsi tentunya ada beberapa faktor, yaitu faktor ekonomi, geografis, waktu, sosial, budaya dan banyaknya siswa drop out dari SMA adalah kendala dari rendahnya APK Pendidikan Menengah (Dikmen).

Dengan latar belakang MDGs dan APK diatas maka usulan kegiatan ini dibuat untuk memberikan kontribusi pada proses pencapaian MDGs dan peningkatan angka APK khususnya di satuan daerah pedesaan.

Pada Tabel 1 (data dari laporan (Kementrian Keuangan, 2012)), dapat dilihat APK dan APM Kabupaten Garut adalah 121,5 dan 99,11 untuk tingkat SD serta 88,59 dan 66,62 untuk tingkat SMP. Dapat dilihat dengan APM 66,62 untuk tingkat SMP dapat disimpulkan bahwa masih terdapat 33,38 persen tidak melanjutkan ke jenjang SMU. Salah satu upaya yang dipandang dapat dilakukan untuk membantu peningkatan angka partisipasi murni dan kasar tersebut adalah dengan penyelenggaraan pendidikan non formal bagi para siswa putus sekolah maupun mereka yang tidak memiliki ijazah kelulusan sekolah.
Tabel 1. Angka Partisipasi Kasar dan Angka Partisipasi Murni Jawa Barat (Kementrian Keuangan, 2012)

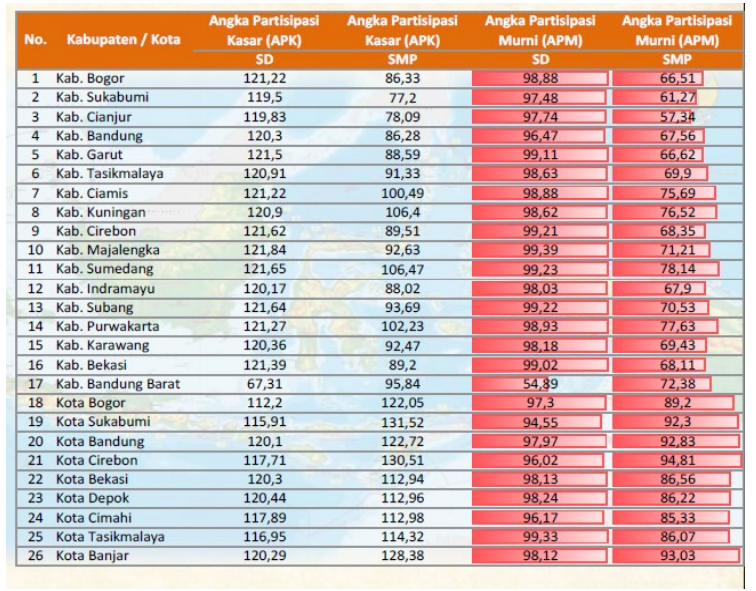

\section{Pendidikan Formal, Nonformal, Informal dan} Usia Dini

Merujuk pada UU Pendidikan Nasional No 20 Tahun 2003 , beberapa definisi pendidikan diberikan sebagai berikut:

1. satuan pendidikan adalah kelompok layanan pendidikan yang menyelenggarakan pendidikan pada jalur formal, nonformal, dan informal pada setiap jenjang dan jenis pendidikan,

2. pendidikan formal adalah jalur pendidikan yang terstruktur dan berjenjang yang terdiri atas pendidikan dasar, pendidikan menengah, dan pendidikan tinggi,

3. pendidikan nonformal adalah jalur pendidikan di luar pendidikan formal yang dapat dilaksanakan secara terstruktur dan berjenjang,

4. pendidikan informal adalah jalur pendidikan keluarga dan lingkungan

5. pendidikan anak usia dini adalah suatu upaya pembinaan yang ditujukan kepada anak sejak lahir sampai dengan usia enam tahun yang dilakukan melalui pemberian rangsangan pendidikan untuk membantu pertumbuhan dan perkembangan jasmani dan rohani agar anak memiliki kesiapan dalam memasuki pendidikan lebih lanjut.

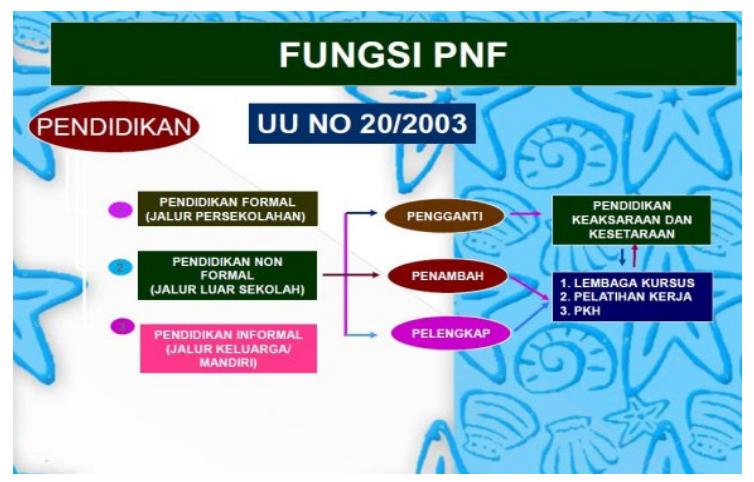

Gambar 1. Fungsi Pendidikan Nonformal 
Penyelenggaraan pendidikan nonformal hanya dapat dilaksanakan oleh :

1. lembaga kursus dan lembaga pelatihan adalah satuan pendidikan non formal yang terdiri atas sekumpulan warga masyarakat yang memberikan pengetahuan, keterampilan dan sikap mental tertentu bagi warga belajar,

2. kelompok belajar adalah satuan pendidikan non formal yang terdiri atas sekumpulan warga masyarakat yang saling membelajarkan pengalaman dan kemampuan dalam rangka meningkatkan mutu dan taraf kehidupannya,

3. pusat kegiatan belajar masyarakat adalah satuan pendidikan non formal yang menyelenggarakan berbagai kegiatan belajar sesuai dengan kebutuhan masyarakat atas dasar prakarsa dari, oleh dan untuk masyarakat.

\section{Pusat Kegiatan Belajar Masyarakat}

PKBM adalah lembaga yang dibentuk oleh masyarakat untuk masyarakat yang bergerak dalam bidang pendidikan. PKBM ini masih berada di bawah pengawasan dan bimbingan dari Dinas Pendidikan Nasional. PKBM ini dapat diselenggarakan di tingkat desa ataupun kecamatan. Untuk mendirikan PKBM, syarat kelembagaan yang harus dipenuhi Akta Notaris, NPWP, Susunan Badan pengurus, Sekretariat. Ijin Operasional dari Dinas Pendidikan Kabupaten atau Kota.

Cakupan kegiatan PKBM antara lain Kejar Paket A, Kejar Paket B, Kejar Paket C, PAUD (Pendidikan Anak Usia Dini), KBU (Kelompok Belajar Usaha), KUPP (Kelompok Usaha Pemuda Produktif)m Pemberdayaan Perempuan, Keaksaraan Fungsional Dasar Dewasa, Taman Bacaan Masyarakat (Perpustakaan).

\section{METODA PENYELESAIAN MASALAH}

Kegiatan PPM Prioritas Universitas Padjadjaran 2014 ini dilaksanakan dalam rangka mendukung pencapaian tujuan MDGs 2 dan MDGs 3 dengan cara memberikan upaya untuk dapat meningkatkan Partisipasi dan Penyelesaian Sekolah Dasar dan Menengah di Pedesaan Jawa Barat. Dalam hal ini, realisasi kegiatannya diwujudkan dalam bentuk:

1. pendidikan masyarakat

2. konsultasi

3. pelatihan

4. simulasi Ipteks

5. teknik pengumpulan data

\section{KARYA UTAMA}

Dari pelaksanaan metode penyelesaiana masalah, kami telah berhasil melaksankan sembilan jenis kegiatan, yaitu:

a. penelusuran Pusat Kegiatan Belajar Masyarakat (PKBM) yang ada di Kecamatan Jatinangor Kabupaten Sumedang dan Kecamatan Bayongbong Kabupaten Garut, dimana PKBM ini adalah salah satu lembaga yang diijinkan oleh Dinas Pendidikan dalam hal penyelenggaran Pendidikan Non Formal (PNF),

b. bekerjasama dengan Unit Pelaksana Teknis Daerah (UPTD) TK/PAUD dan PNF Kecamatan
Jatinangor dalam hal mendukung kegiatan warga belajar di Program Kejar Paket C Al Qurtubi di Desa Jatimukti Kecamatan Jatinangor Kabupaten Sumedang,

c. mencari informasi mengenai tatalaksana Program Kejar Paket $\mathrm{C}$ dengan cara menghubungi Dinas Pendidikan Sumedang dalam hal ini Kepala Seksi Pendidikan Masyarakat Dinas Pendidikan Sumedang telah menjadi narasumber kami dalam hal penelusuran dan pendataan analisis kebutuhan Program Kejar Paket C,

d. memberikan suplemen pengajaran untuk warga belajar Program Kejar Paket C Al Qurtubi di Desa Jatimukti Kecamatan Jatinangor Kabupaten Sumedang, dimana Kelompok Belajar Al Qurtubi ini merupakan satu-satunya penyelenggara program kejar paket C se-Kabupaten Sumedang.

e. memberikan pendampingan pada perangkat masyarakat terkait untuk pembentukan Pusat Kegiatan Belajar Masyarakat yang dilakukan di Desa Mekarjaya Kecamatan Bayongbong Kabupaten Garut,

f. dalam hal ini telah dilaksanakan pendampingan untuk RAAl Maasy dan Kelompok Bermain Insan Rabbani, dalam hal pembentukan Taman Bacaan Masyarakat dengan memberikan sumbangan Alat Permainan Edukatif dan Buku Bacaan Anak-anak,

g. memberikan bantuan sarana kepada Pusat Kegiatan Belajar Masyarakat Linuhung yang terletak di Desa Cibeusi Kecamatan Jatinangor Kabupaten Sumedang, sebagai bentuk dukungan keberlangsungan PKBM dalam hal mewujudkan meningkatnya angka partisipasi dan penyelesaian sekolah tingkat dasar,

h. mengumpulkan data naskah ujian Kejar C dan membantu penggandaan materi yang akan diujikan,

i. memperoleh data APM Kecamatan Jatinangor Kabupaten Sumedang dari UPTD TK/SD dan PNF Kecamatan Jatinangor Kabupaten Sumedang,

j. secara umum, penelaahan terhadap system pendidikan non formal di lokasi PPM, dilakukan dengan metodologi penelitian secara deskriptif kualitatif dengan teknik pengumpulan data yang digunakan adalah wawancara, observasi, dan dokumentasi,

k. memberikan sharing knowledge dalam bentuk Pelatihan Learning Skills yang telah diselenggarakan pada tanggal 5 Desember 2014 bertempat di FMIPA Universitas Padjadjaran. Pelatihan ini meliputi pemberian materi dalam hal menumbuhkan motivasi, berfikir kreatif, management waktu dan manajemen Stress.

\section{ULASAN KARYA}

\section{Faktor Pendorong dan Penghambat}

Sikap yang sangat kooperatif dari UPTD TK/ SD dan PNF Kecamatan Jatiangor, PKBM Linuhung, Kepala Desa Jatimukti dan Kepala Desa Jatimukti, Koordinator Program Kejar Paket C Al-Qurtubi, Kepala RAAl Maasy dan Kepala Kelompok Bermain Insan Rabbani serta semua pihak yang terlibat sangat membantu dalam pelaksanaan kegiatan. 
Untuk pendampingan Program Kejar Paket C di Desa Jatimukti kami mencatat bahwa:

1. aspek kognitif, psikomotorik dan afektif warga belajar dalam hal penguasaan materi ujian nasional kesetaraan dapat dinilai rendah. Sementara itu dalam kurun waktu kurang dari 6 bulan, peserta program kejar paket $\mathrm{C}$ ini akan mengikuti ujian nasional kesetaraan. Hal ini terlihat dari hasil pre-test dan post-test yang dilakukan pada dosen pelaksana kegiatan,

2. beragamnya latar belakang,

3. pendidikan dan ekonomi dari warga belajar mengakibatkan pelaksanaan kegiatan belajar mengajar seringkali dihadiri oleh warga belajar dengan jumlah yang sedikit. Sehingga dapat dinilai bahwa tingkat konsistensi warga belajar dalam mengikuti Program Kejar Paket C masih rendah. Dari 30 orang warga belajar yang terdaftar, rata-rata jumlah warga belajar yang hadir adalah 8 orang (selama pengamatan dari 9 kunjungan yang kami lakukan) atau masih kurang dari 30\% pada setiap sesi yang diselenggarakan,

4. program kejar paket ini harus diikuti oleh warga belajar selama kurun waktu yang pernah mereka tempuh, mengakibatkan motivasi untuk mengikuti program turun dan naik,

5. sarana prasarana belajar dinilai kurang memadai. Bantuan dari Dinas Pendidikan Sumedang berupa modul pembelajaran paket $\mathrm{C}$ tidak dapat dimiliki oleh warga belajar, karena keterbatasan dana,

6. kemampuan para tutor program kejar paket $\mathrm{C}$ ini sebaiknya ditingkatkan. Dari hasil wawancara dapat diketahui bahwa tingkat pemahaman tutor terhadap materi ujian nasional kesetaraan masih harus ditinjau ulang,

7. para tutor sendiri mengakui bahwa mereka tidak memiliki buku pegangan,

8. dalam masa pelaksanaan pendampingan pengajaran, tutor mata pelajaran tidak pernah hadir. Sehingga tim PPM Prioritas Unpad sulit berkoordinasi mengenai upaya peningkatan kualitas belajar mengajar di Program Kejar Paket C ini.

Dalam hal pembentukan PKBM di Desa Mekarjaya, kami mencatat beberapa hal antara lain sebagian besar masyarakat yang mendengar rencana pendampingan untuk program Kejar Paket C di Desa Mekarjaya berharap bahwa proses perolehan ijazah kesetaraan dapat dicapai dalam waktu singkat.

\section{DAMPAK DAN MANFAAT KEGIATAN}

Berdasarkan hasil analisis situasi pada lokasi PPM Prioritas yang telah kami pilih serta analisis pada faktor penghambat yang telah dipaparkan pada subseksi 4.1, maka upaya yang kami laksanakan adalah

1. memberikan suplemen materi pengajaran berupa kumpulan soal Ujian Nasional Kesetaraan Program Paket C (Lihat Lampiran 2),

2. memberikan bantuan sarana alat tulis untuk semua mitra PKBM,

3. mengundang Yayasan Linuhung selaku pengelola PKBM Linuhung di Desa Cibeusi kami jadikan PKBM percontohan bagi Desa Jatimukti dan Desa
Mekarjaya. Dalam hal ini Desa Jatimukti dan Desa Mekarjaya dipilih sebagai lokasi PPM yang belum memiliki PKBM. Sehingga diharapkan pendampingan bagi Desa Jatimukti dan Mekarjaya dapat berlanjut di masa yang akan datang, dalam hal pendampingan pembentukan PKBM dengan menambahkan beberapa kegiatan masyarakat dalam hal ini termasuk memberikan bantuan pada RA Al Maasy dan Kelompok Bermain Insan Rabbani, serta diharapkan dapat terbentuk taman bacaan masyarakat, kelompok belajar kejar paket c, serta kelompok usaha serta pelatihan/kursus,

4. menghadirkan dosen pendamping tambahan untuk mata pelajaran Bahasa Inggris (Dianne Amor Kusuma, M.Pd) dan PPKN (Meilann Budiarti,M.Si),

5. memberikan Pelatihan Learning Skills yang merupakan pelatihan pengenalan diri (selfassesment) bagi para tutor/guru dan warga belajar yang terlibat di PKBM, dengan materi yang meliputi menumbuhkan motivasi, berfikir kreatif, manajemen waktu, manajemen stress.

Secara umum, hasil dari kegiatan ini menunjukkan peningkatan antusiasme belajar dari warga belajar, tutor, pengelola PKBM serta para guru TK/PAUD. Pada Gambar 3 dapat dilihat distribusi peserta dari 6 mitra yang kami undang. Diharapkan kegiatan ini dapat meningkatkan angka partisipasi dan penyelesaian sekolah tingkat dasar dan menengah.

\section{SIMPULAN}

Menilik lebih dekat mengenai program pemerintah dalam hal pendidikan non formal memberikan kesempatan untuk Universitas Padjadjaran untuk dapat berperan secara langsung dalam pencapaian Indonesian Millenium Developments Goals. Selain itu, kegiatan ini pun membuka mata pihak penyelenggara pendidikan tinggi, bahwa masyarakat di pedesaan masih banyak yang belum dapat menyelesaikan pendidikan tingkat dasar dan menengah. Secara khusus dapat disimpulkan bahwa perlu adanya pelatihan bagi tutor program paket $C$ untuk memastikan bahwa para tutor mampu meningkatkan kemampuan kognitif, psikomotorik dan afektif dari para warga belajar. Pembentukan Pusat Kegiatan Belajar Masyarakat sangat perlu dikembangkan untuk membantu percepatan peningkatan angka partisipasi pendidikan tingkat dasar dan menengah. Aspek afektif dan Sikap kedisiplinan warga belajar belum sepenuhnya terbentuk. Hal ini terlihat dari masih banyaknya warga belajar yang datang terlambat dan suka berbicara saat proses pembelajaran, serta rendahnya tingkat kehadiran warga belajar. Upaya memperbaiki motivasi, cara berpikir, manajemen waktu dan managemen stress perlu diberikan secara kontinyu.

Salah satu kendala yang dihadapi oleh tim pelaksana PPM adalah tidak dapat melihat hasil pembelajaran secara kuantitatif, dikarenakan periode pelaksanaan PPM hanya 4 bulan. Sementara itu, program kejar paket $C$ harus diikuti selama 3 tahun. Selain itu, untuk pendampingan pembentukan proposal pun, kendala waktu menjadi hambatan. Untuk itu disarankan untuk bahwa kegiatan ini sebaiknya dicanangkan untuk periode waktu pelaksanaan minimal 3 tahun. 


\section{DAFTAR PUSTAKA}

Ashari, D. (2013). Model Pembelajaran Warga Belajar Kejar Paket C Di Tinjau Dari Prestasi Belajar Di FSanggar Kegiatan Belajar Gunungpati Kota Semarang. Semarang: Skripsi pada Jurusan Pendidikan Luar Sekolah Universitas Negeri Semarang.

BAPPENAS. (2012). Laporan Perkembangan Pencapaian Tujuan Pembangunan Milenium Indonesia. BAPPENAS.

Bupati. (2011). Peraturan Daerah Kabupaten Garut No 11 Tahun 2011. Garut: Pemerintah Daerah Kabupaten Garut.
Kementrian Keuangan, R. (2012). Tinjauan Ekonomi dan Keuangan Daerah Jawa Barat.

Kurnia, G. (2013, September). Pidato Rektor Universitas Padjadjaran pada Dies Natalies Unpad ke-56. Retrieved April 27, 2014, from http://www.unpad.ac.id/arsip-unpad/pidatorektor/. Masyarakat, P. P. (n.d.).

Ridwan, M.(2014, Mei 1). http://www.lensaindonesia. com/2014/05/01/apk-pendidikan-di-jabarmasih-rendah.html. Retrieved September 8 , 2014, from http://www.lensaindonesia.com. 